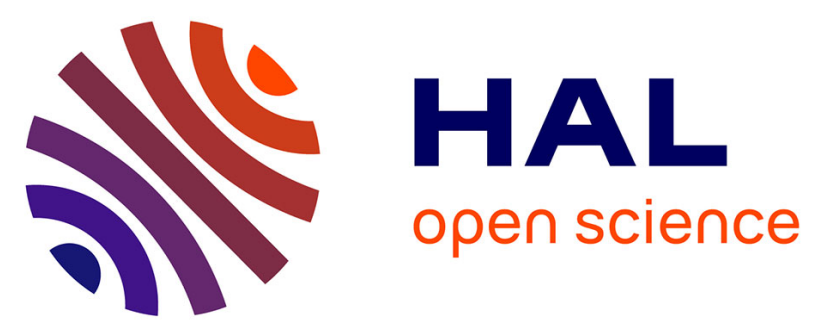

\title{
Architecture of the lower terraces and evolution of the Dordogne River at Bergerac (Southwest France) during the last glacial-interglacial cycle
}

Pascal Bertran, Marine Frouin, Norbert Mercier, Fabien Naessens, Frédéric Prodeo, Alain Queffelec, Colette Sirieix, Luca Sitzia

\section{To cite this version:}

Pascal Bertran, Marine Frouin, Norbert Mercier, Fabien Naessens, Frédéric Prodeo, et al.. Architecture of the lower terraces and evolution of the Dordogne River at Bergerac (Southwest France) during the last glacial-interglacial cycle. Journal of Quaternary Science, 2013, 28, pp.605-616. $10.1002 /$ jqs.2656 . hal-01743133

\section{HAL Id: hal-01743133 \\ https://hal.science/hal-01743133}

Submitted on 11 Jun 2020

HAL is a multi-disciplinary open access archive for the deposit and dissemination of scientific research documents, whether they are published or not. The documents may come from teaching and research institutions in France or abroad, or from public or private research centers.
L'archive ouverte pluridisciplinaire HAL, est destinée au dépôt et à la diffusion de documents scientifiques de niveau recherche, publiés ou non, émanant des établissements d'enseignement et de recherche français ou étrangers, des laboratoires publics ou privés. 


\section{Architecture of the lower terraces and evolution of the Dordogne River at}

\section{Bergerac (south-west France) during the last glacial-interglacial cycle}

PASCAL BERTRAN,${ }^{1,2 *}$ MARINE FROUIN, ${ }^{3}$ NORBERT MERCIER,${ }^{3}$ FABIEN NAESSENS,${ }^{4}$ FREDERIC PRODEO,${ }^{5}$

ALAIN QUEFFELEC, ${ }^{2}$ COLETTE SIRIEIX ${ }^{4}$ and LUCA SITZIA ${ }^{2}$

${ }^{1}$ INRAP, 156 avenue Jean Jaurès, 33600, Pessac, France

${ }^{2}$ PACEA, UMR 5199 Université Bordeaux 1-CNRS, Talence, France

${ }^{3}$ CRPAA, UMR 5060 Université Bordeaux 3, Pessac, France

${ }^{4}$ I2M, UMR 5295 Université Bordeaux 1-CNRS, Talence, France

${ }^{5}$ INRAP, Domaine de Campagne, Campagne, France

\section{Abstract}

The lower terraces of the Dordogne River at Bergerac (south-west France) were studied in detail using cores, trenches, ground penetrating radar profiles, and ${ }^{14} \mathrm{C}$, optically stimulated luminescence and infrared stimulated luminescence dating. This study shows that the lowest terrace (Fx) is made up of two major lithostratigraphic units: (i) dominantly horizontal gravel strata interpreted as compound bar deposits in a braided river, which pre-date 18 $17 \mathrm{ka}$, and (ii) thick lateral accretion gravel units (point bars) formed in an anabranching river during the Late Pleniglacial and Lateglacial. Most of the anabranching channels were abandoned at ca. 11-10 ka following shrinkage of the river bed into a single meandering channel and were partially filled by gyttjas during the Boreal chronozone. Finally, the channels were plugged by overbank fines until about 5 ka. Floods seldom reached the Fx terrace during the late Holocene and accretion became negligible. The main phase of bedrock incision spanned the Holocene, whereas the period of channel adjustment to change in river regime during late Marine Isotope Stage (MIS) 2 only led to a redistribution of the Pleniglacial gravels. The higher terrace (Fw3) formed before the Eemian and was covered by colluvial fans, mainly during MIS 2 and 3.

\section{Keywords}

Dordogne River; fluvial dynamics; Holocene; south-west France; Weichselian.

\section{Introduction}

The formation of alluvial terraces has generated many geomorphological studies over the past few decades and still remains a widely debated subject. Different models have been proposed to explain bedrock erosion, deposition and terracing in relation to tectonic, climatic and intrinsic (autogenic) factors (Vandenberghe, 2008; Bridgland and Westaway, 2008, 2012; Lewin and Gibbard, 2010; Murton and Belshaw, 2011, and additional references therein). One of the main difficulties in evaluating the validity of the various hypotheses usually resides in the limited range of available data concerning both the geometry and the chronology of the alluvial bodies preserved in the terraces. Although the recent development of quartz or feldspar luminescence dating methods has significantly increased the possibilities of obtaining age information from alluvial deposits and enabled refinement of the chronological frameworks, most studies are based on observations of distant sections or cores and fail to take account of the real 
complexity of the terrace architecture. Therefore, establishing accurate links between river evolution and the various forcing factors remains difficult.

The development of rescue archaeology in France over the past few years has provided abundant, closely spaced observation windows in alluvial terraces, mainly around large towns currently undergoing rapid expansion. Bergerac in south-west France, located in the middle course of the Dordogne River, is one of these towns (Fig. 1). Over the past 5 years, all the geotechnical cores and archaeological trenches dug in the lower terraces near the town have been surveyed and various elements have been gathered for dating [archaeological remains, samples for radiocarbon and optically stimulated and infrared stimulated luminescence (OSL/IRSL)]. At two sites, these data have also been complemented by ground penetrating radar (GPR) profiles. Brought together, the data allow us to map in detail the alluvial deposits and to document their architecture and depositional history, thereby providing a high-resolution picture of river changes during the last glacial-interglacial transition.

\section{Regional setting}

The Dordogne is a large river flowing in south-west France westward to the Atlantic Ocean. In the study area, which is located in the middle course of the river, the valley is ca. $7 \mathrm{~km}$ wide and bordered by outcrops of Eocene alluvial sands (e5, Platel, 1985), overlain by fluvial-deltaic clays, sands and marls (e6-7) (Fig. 1). The underlying Cretaceous limestones do not outcrop on the slopes but form the bedrock of the current channel. Two main terraces, labelled Fx and Fw3 on the 1:50 000 geological map (Platel, 1985), are preserved on either side of the current river floodplain (Fz) (Supporting information Fig. S1). Older terrace remnants are also visible on the slopes (Fw2 to Fu). Available core data show that they form a system of platforms cut into the substrate and covered by $5-7 \mathrm{~m}$ of alluvial deposits, forming typical paired (although unequally developed) stepped units (Lewin and Gibbard, 2010). Abundant archaeological remains spanning the last two glacial- interglacial cycles have been found in this part of the valley and attest to recurrent human settlement since the Middle Palaeolithic. This article focuses on the two lower units.

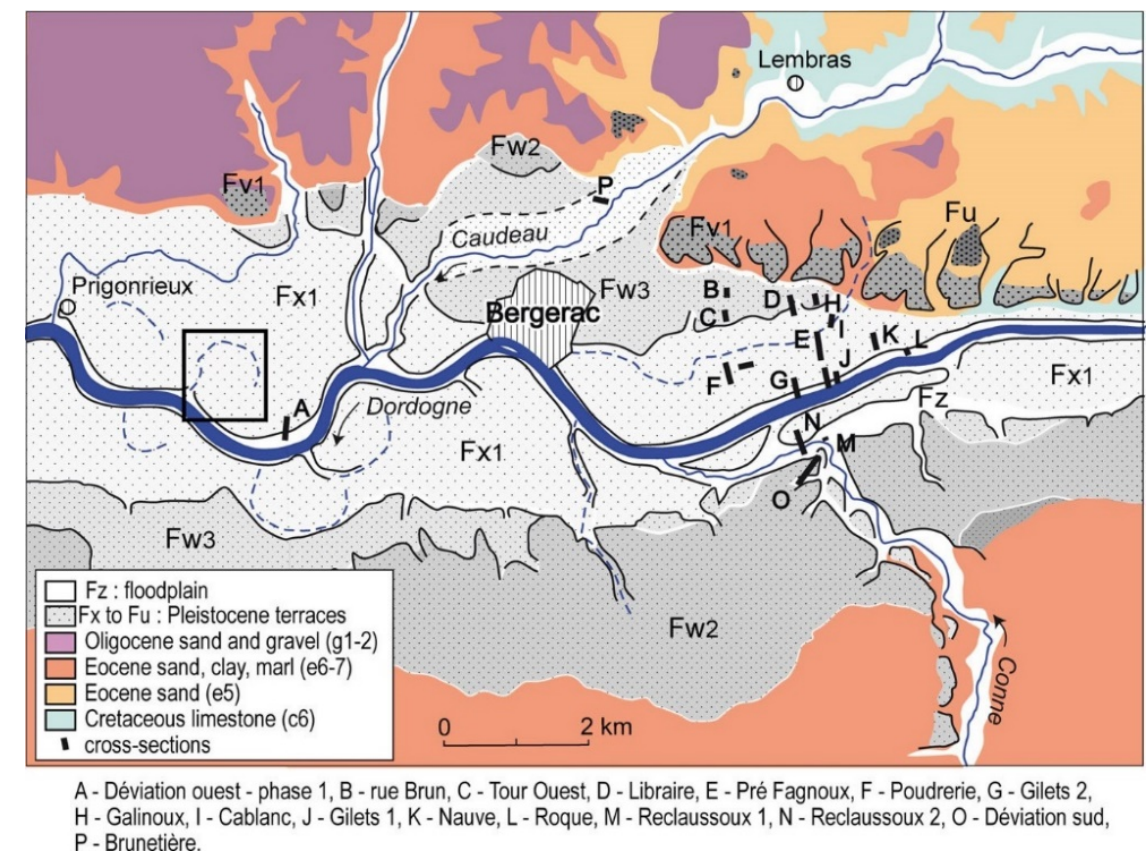

Figure 1. Geological map of the study area, simplified after Platel (1985), and location of the cross-sections. The rectangle indicates the location of Fig. 7. This figure is available in colour online at wileyonlinelibrary.com. 


\section{Materials and methods}

The archaeological trenches are generally $1.5-3 \mathrm{~m}$ deep and $20 \mathrm{~m}$ long and allow for the detailed observation of the finegrained lithostratigraphic units overlying the gravel bodies. The latter have only occasionally been exposed by the trenches. Complementary information was obtained from geotechnical cores and auger or penetrometer data. In addition, GPR profiles were collected with a 200-MHz antenna and a Radar SIR System-3000 GSSI (Geophysical Survey systems, Inc., Salem, MA, USA). Data were collected at 16 bits per sample, 64 scan s ${ }^{1}$ over $120 \mathrm{~ns}$. The raw GPR data were processed using RADAN software, which included bandpass filtering (30-400MHz), gain adjustment and stacking (16). Direct measurement was used to estimate velocity (with a target at a known depth) on one of the investigated sites. Based on this estimation a velocity of $0.134 \mathrm{mns}^{1}$ was selected for data processing. Several profiles were made in this way. However, it was only possible to exploit the first radar campaign as the following profiles made 2 years later were strongly perturbed by noise of unknown origin.

The lithostratigraphic units were sampled for chemical analysis and for dating. Samples for chemical analysis were analysed by energy-dispersive X-ray-fluorescence analysis (ED-XRF) using a portable SPECTRO X-SORT device $(40 \mathrm{kV}, 50 \mathrm{~mA})$, after separation into two fractions by wet sieving at $63 \mathrm{~mm}$ and grinding the sand fraction. Measurements were made in air with an acquisition time of $60 \mathrm{~s}$ and replicated three times. They displayed good reproducibility. Elements lighter than $\mathrm{Si}$ were not detected with this method. The chemical compositions were then compared with those stored in the PACEA geochemical database obtained from different geological formations in the same geographical sector. All data underwent a multivariate statistical analysis. Since the application of classic statistics to compositional data (e.g. data expressed as percentages) is not correct and can lead to partial or even erroneous interpretations (Buccianti, 2012), the approach introduced by Aitchison (1982) was followed. In this paper, the biplot for compositional data was chosen as a tool for multivariate analysis (Aitchison and Greenacre, 2002). Values below the detection threshold were treated in accordance with the method proposed by MartinFernandez et al. (2003) before analysis. Only elements for which more than $80 \%$ of the values were higher than the detection threshold were used in the analysis, made with the CoDaPack software (Thio-Henestrosa and Comas, 2011).

Thin sections were also prepared from undisturbed samples from the Rue Brun site, after vacuum impregnation with a polyester resin following the method proposed by Guillore' (1980), and observed with a petrographic microscope. Radiocarbon dating was carried out on charcoal or peat samples. OSL dating was applied to quartz grains and IRSL to feldspar. The dose accumulated by the grains was calculated using a single aliquot regenerativedose protocol (SAR; Murray and Wintle, 2000). For feldspars, two distinct approaches were nonetheless applied. The IR-postIR $225^{\circ} \mathrm{C}$ protocol (Buylaert et al., 2009) was applied to samples from Tour Ouest and Nauve, whereas

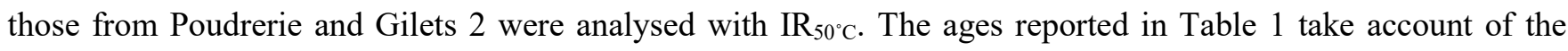
corrections linked to the fading rate (Auclair et al., 2003; Thomsen et al., 2008) and to the residual signals specific to each approach, as well as dose rates measured in situ with a gamma spectrometer. 


\section{Lithostratigraphy}

\section{Terrace Fw3}

Terrace Fw3 forms a vast surface dipping gently towards the Dordogne River. Such morphology may indicate the presence of a colluvial cover overlying fluvial sediments. The deposits were observed in trenches at several sites (Tour Ouest, Rue Brun, Libraire and Galinoux; Fig. 2). The depositional sequence shows, from bottom to top:

A gravel body about $5 \mathrm{~m}$ thick, with a base at approximately $30-31 \mathrm{~m}$ above sea level (a.s.l). This unit (T3a) has only been observed from geotechnical cores. It is interpreted as coarse-grained channel or bar deposits.

Massive dominantly sandy deposits, 3-6m thick (T3b, c). Near the slope, they include clast- to matrix-supported gravel beds (Dmc, Dmm; Miall, 1996). The distal part of this unit becomes siltier. The overall massive character suggests a gradual homogenization of the sediments during deposition (bioturbation, freeze-thaw cycles) or emplacement as mudflows. These deposits are interpreted as coalescent colluvial fans. Overbank sandy silt inputs from the Dordogne may also have contributed. This question is tackled using geochemistry. At Rue Brun, a complex palaeoluvisol makes up a major chronostratigraphic limit within the sands and allows us to divide these deposits into two subunits, T3b at the bottom and T3c at the top. Unit T3c yielded Upper Palaeolithic industries in different places (i.e. Aurignacian, Magdalenian, indeterminate Upper Palaeolithic: Prodeo et al., 2001; Grigoletto, 2010).

The various observation windows provide complementary information with regard to the geometry of the units. At Libraire, the core data indicate that the T3a and $\mathrm{b}$ units were cut by a gully perpendicular to the valley and filled afterwards by mainly sandy sediments. No evidence for the interglacial palaeoluvisol was observed in this crosssection. A major unconformity thus separates unit T3b from unit T3c. These are interpreted as two interlocking sedimentary lobes of a segmented colluvial fan, possibly because of base-levelinduced distal trenching (Harvey, 1997). 


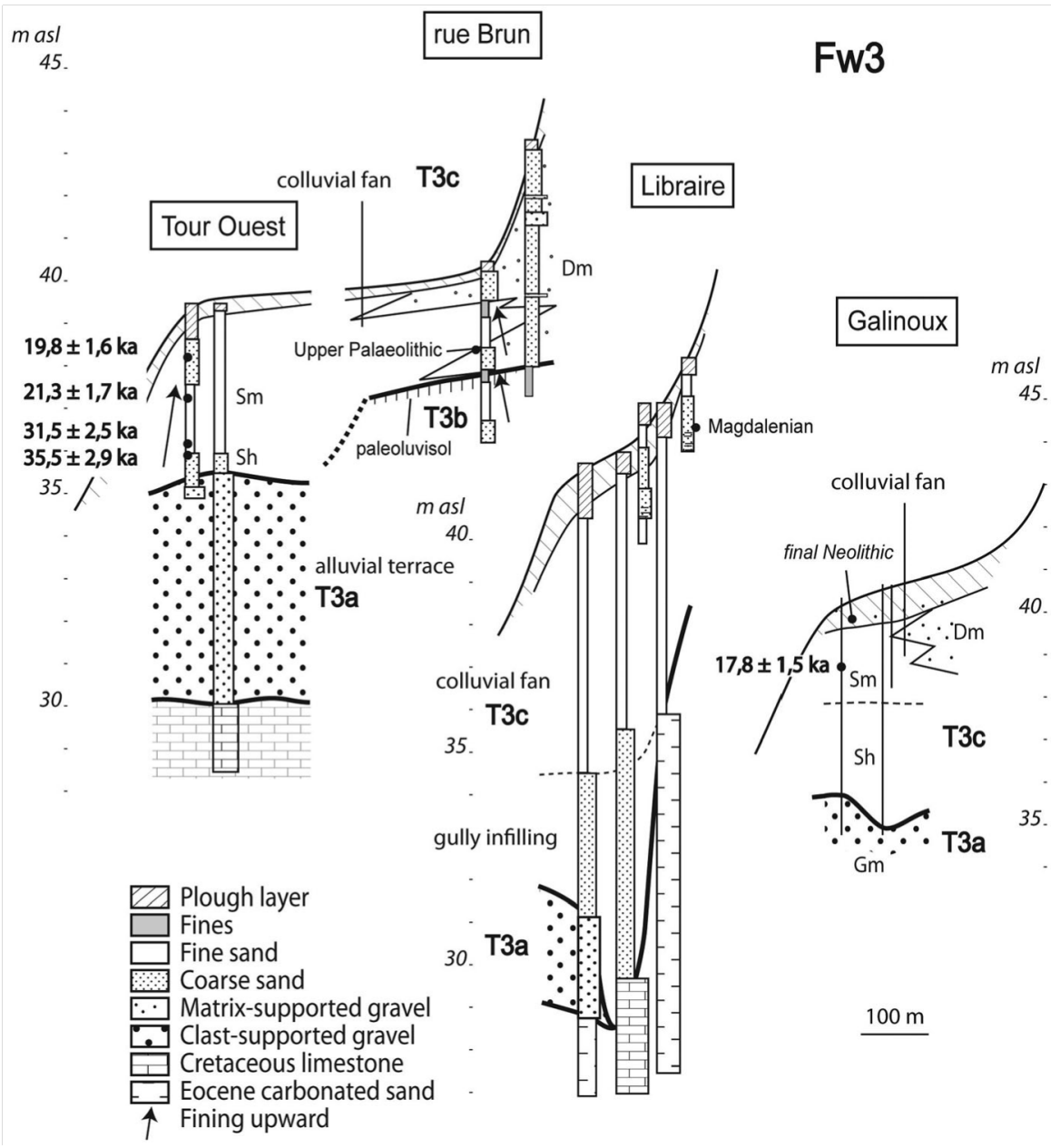

Figure 2. Cross-sections of terrace Fw3.

\section{Terrace Fx}

Terrace Fx makes up a wide berm bordered by levees (Fig. 3). Downstream from Bergerac where the terrace widens, oxbow depressions make it possible to identify former abandoned channels (Fig. 1). Numerous observation windows are available in this terrace (Cablanc, Gilets 1 and 2, Nauve, Poudrerie, Pre' Fagnoux, Roque). In addition to a probable isolated remnant of Fw3 in the Pre' Fagnoux site, the following units were observed (Fig. 4):

A gravel body about $5 \mathrm{~m}$ thick overlying the limestone bedrock. The base is located at a relatively constant altitude in the study area, at about $27-28 \mathrm{~m}$ a.s.1. The GPR profiles indicate that this unit is not homogeneous. Two types of architectural elements are be identified:

Unit T2a comprises dominantly horizontal strata and subordinate oblique sets of strata typically $0.3-0.6 \mathrm{~m}$ thick, interpreted as compound bar deposits, and concave-upward strata corresponding to scour fills (Vandenberghe and van Overmeeren, 1999; Lunt and Bridge, 2004; Sambrook et al., 2006) (Fig. 5). This unit indicates primarily vertical accretion of the deposits, presumably associated with a braided fluvial style.

Unit T2b is composed of low-angle oblique strata, interpreted as lateral accretion features of wide meandering channels (point bars) (Figs. 5 and 6). This unit cuts into and drapes unit T2a. The strata are subhorizontal and regular on the GPR profiles parallel to the channels.

Finer-textured units, corresponding to channel or depression fills. Two main types were observed: Filling of small depressions forming sub-parallel furrows at the top of unit T2b (supporting Fig. S2). These furrows and associated gravel ridges are interpreted as scroll bars (Leclerc and Hickin, 1997). Similar scroll bars are visible on aerial photos in the convexity of an abandoned meander downstream of Bergerac (Fig. 7). The fill (maximum thickness 
of 1-2m) was mainly observed at Cablanc and Pre' Fagnoux. From bottom to top, it generally exhibits crossbedded sands (St, Sr; Miall, 1996), horizontally bedded sands (Sh) and, lastly, laminated to massive sands, silts and sometimes clays (fl, Fm). Polygonal networks of cracks $1 \mathrm{~m}$ in length cut into these deposits in places. These cracks are thought to result from (cryo-) desiccation of the deposits in a deep seasonal frost context (Van VlietLanoe", 1985; Bertran et al., 2013).

Wide channel fills, visible both in cross-section and on the maps of gravel isobaths (T2c) (Fig. 3; supporting Fig. S3). This filling comprises generally massive sand units (Sm) then a fine-grained plug (Fm: silts and sands, gyttjas), often with a thickness of over $1 \mathrm{~m}$. On the Gilets 2 site, the basal sand unit, which forms a body dipping gently towards the channel (point bar), has yielded several prehistoric occupation levels attributed to the Mesolithic.

A general cover by a sandy silt unit which thickens to form a levee on the terrace margin. This unit corresponds to overbank deposits. Recent Neolithic remains were found in the subsurface at several points and show that Fx was seldom reached by floods from the Subboreal onwards. Protohistoric, antique and medieval remains are reworked in the ploughed layer.

The architecture of the Fx terrace is thus complex. It shows (1) a residual gravel unit, which appears to correspond to Fw3 remnants, (2) a thick gravel unit deposited in a braided river (T2a), (3) gravel point bar deposits and associated scroll bars (T2b), and (4) a final fill by fine-grained, sometimes organic deposits (T2c). Scattered depressions with sharp limits are also visible on the maps of gravel isobaths and in trenches (Figs. 3 and 6). They cut into the previous units and correspond to dolines formed along certain channels. Gyttja deposits are trapped at the bottom of these dolines. 

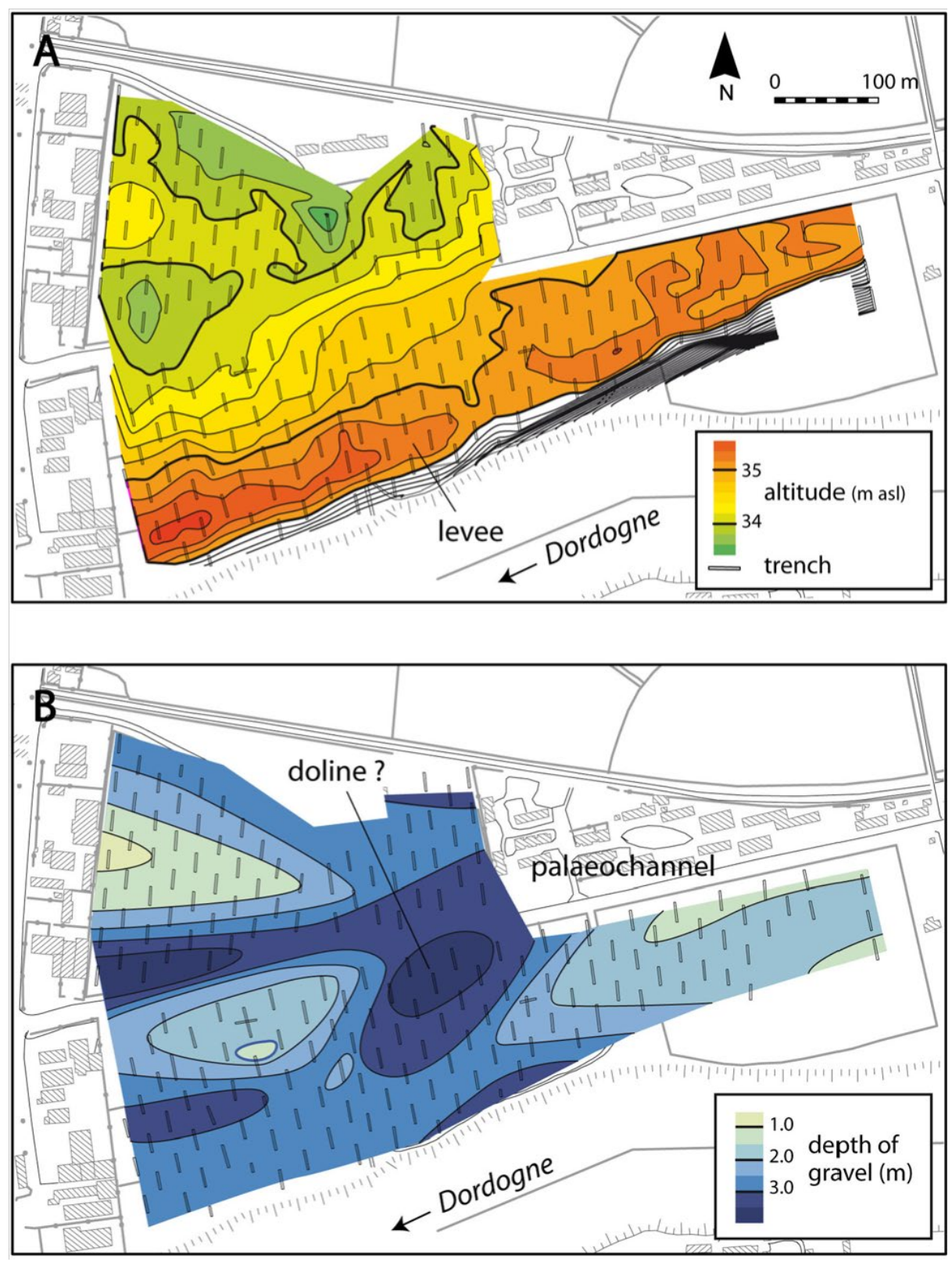

Figure 3. (A) Topography of terrace Fx at the Nauve site; (B) isobath map of the gravels.

\section{Fz floodplain}

The Fz floodplain forms a narrow corridor about $6 \mathrm{~m}$ below Fx and was surveyed at two sites, Roque, which is located slightly upstream from the study area, and Déviation Ouest downstream from Bergerac. The first site only yielded $2 \mathrm{~m}$ of organic sands lying on the limestone bedrock, associated with medieval archaeological remains. The second site shows a channel cut into the Eocene formations and filled by about $4 \mathrm{~m}$ of gravels and sands (Supporting Fig. S4). 


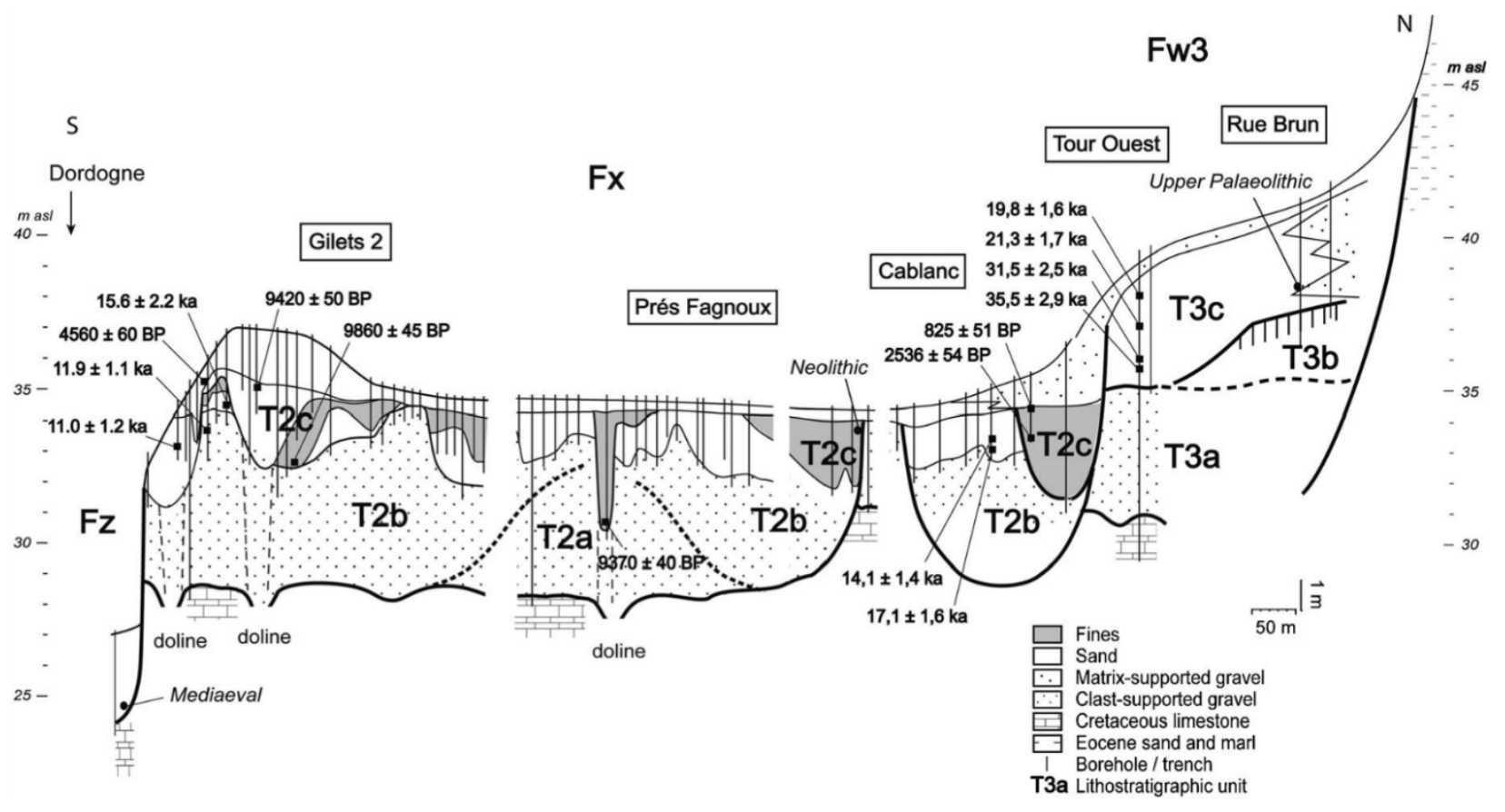

Figure 4. Cross-section of terrace Fx.
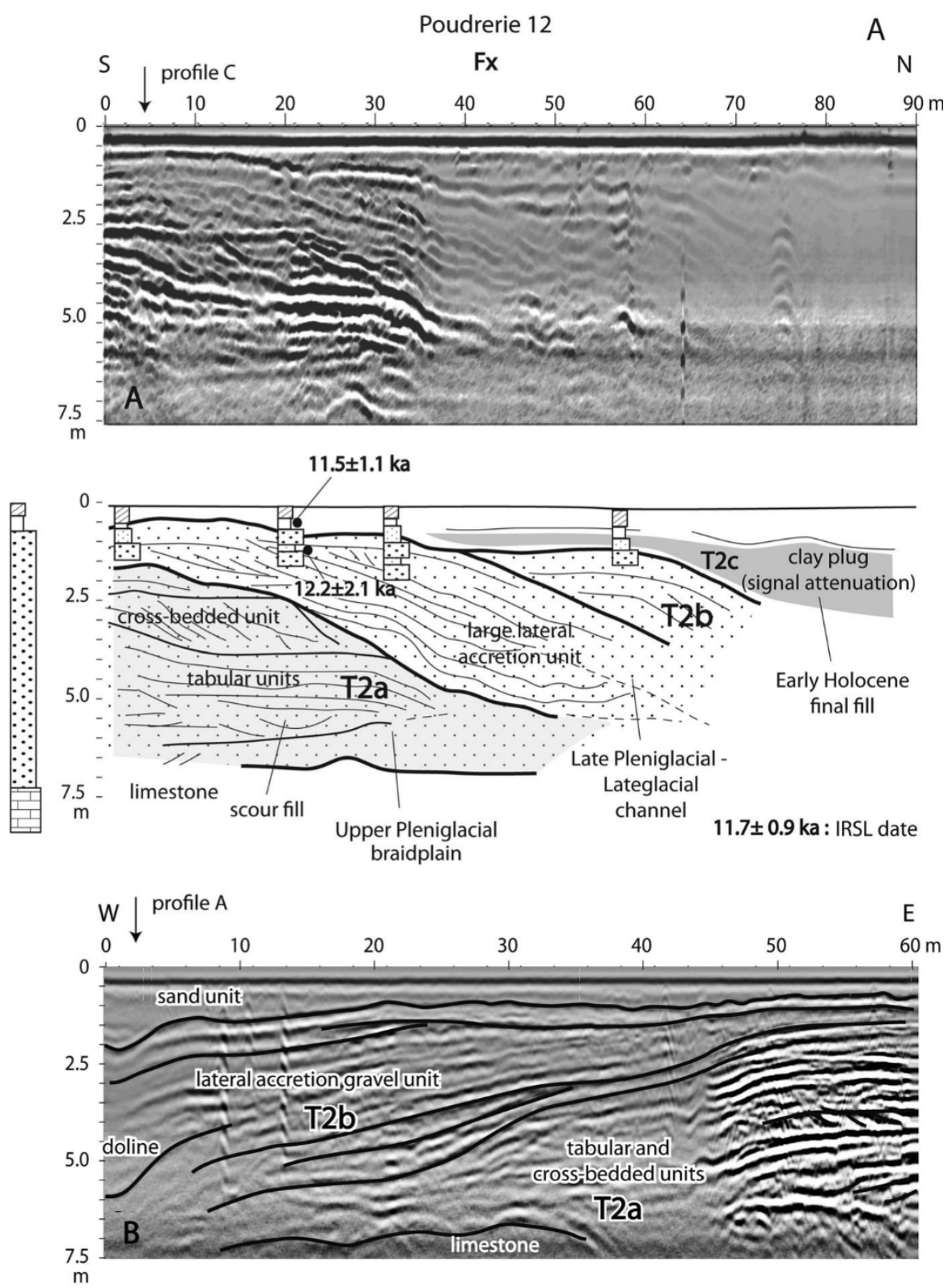

Figure 5. GPR profiles at Poudrerie and interpretation: (A) N-S profile, (B) W-E profile. See Fig. 1 for site location. 


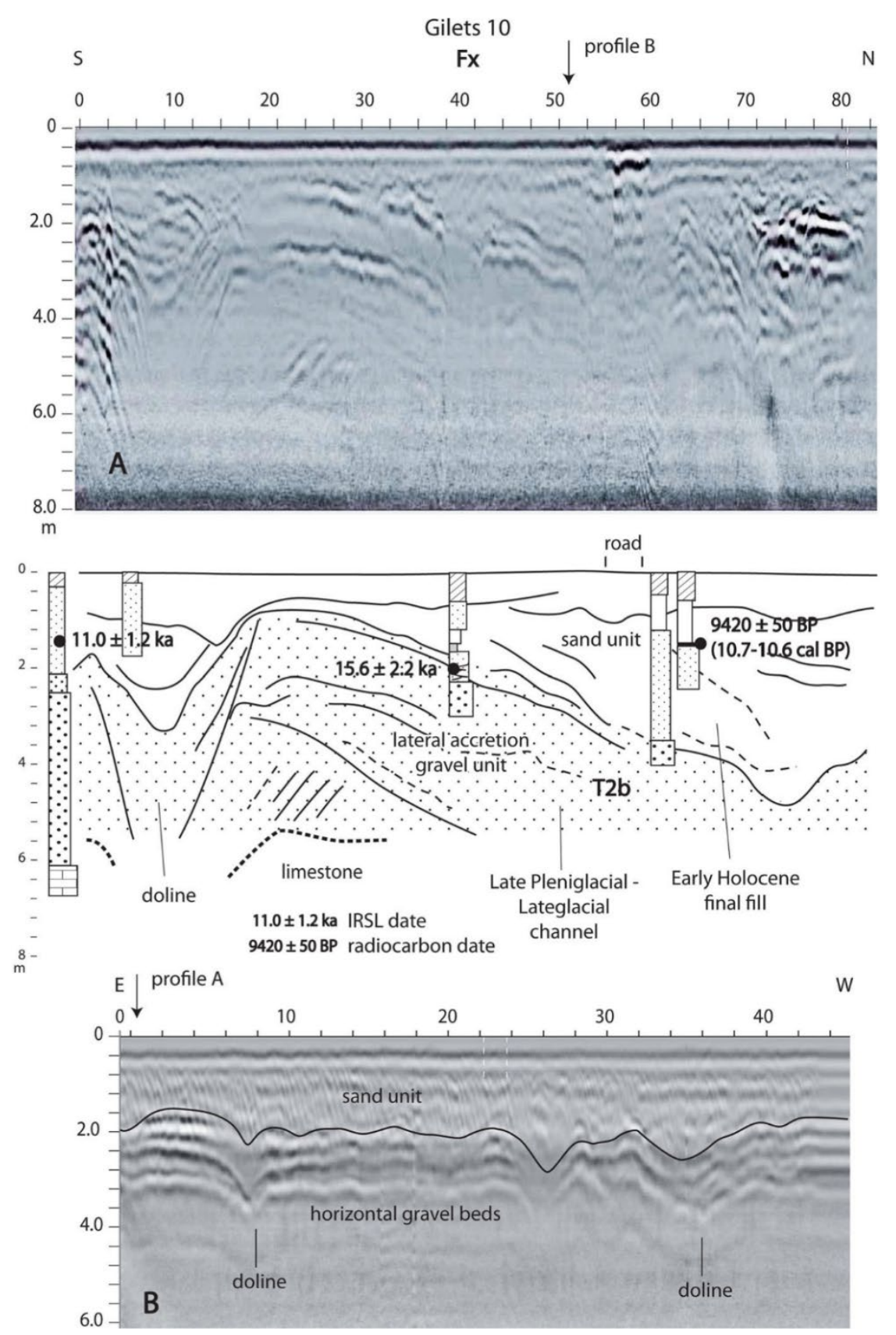

Figure 6. GPR profiles at Gilets 2 and interpretation. (A) N-S profile, (B) W-E profile. See Fig. 1 for site location.

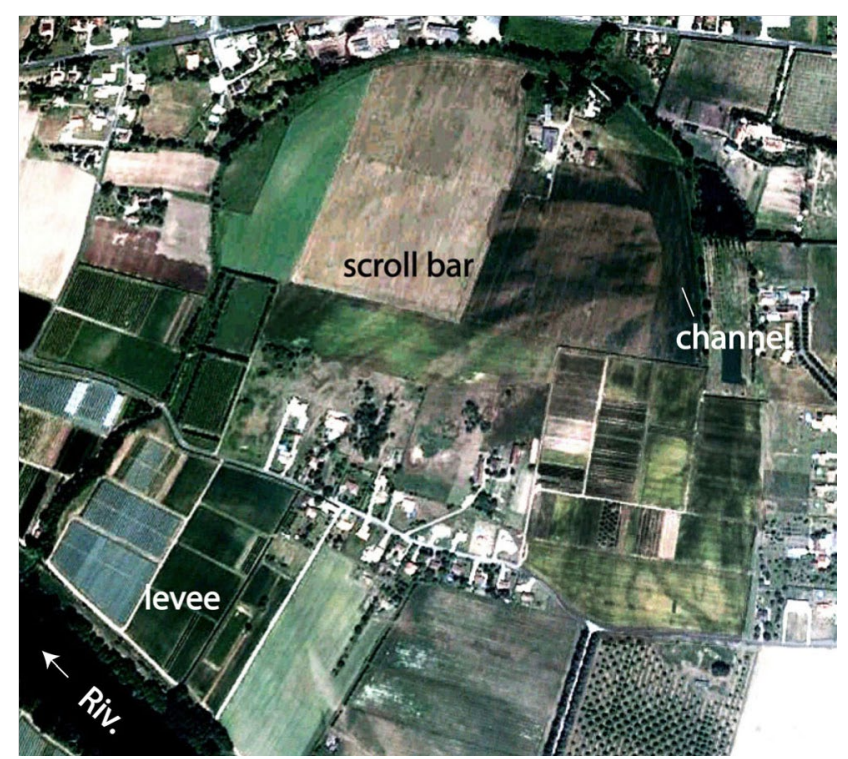

Figure 7. Aerial view of a scroll bar in an abandoned meander downstream of Bergerac (Google earth/IGN). The location of the photo is indicated in Fig. 1. 


\section{Geochemistry}

A geochemical analysis of the sediments from the various formations outcropping in the valley and from other regional sedimentary contexts was undertaken to understand in detail the origin of unit $\mathrm{T} 3 \mathrm{c}$. This analysis brings to light several points. For the sand fraction $(>63 \mathrm{~mm})$, the biplot shows that

(Fig. 8):

The Late Pleistocene deposits of the Dordogne and Garonne Rivers plot close to the calcic pole. In so far as these sediments are decalcified, $\mathrm{Ca}$ comes mainly from plagioclases, but also from ferromagnesian silicates (amphiboles, pyroxenes, epidote). Because calcic minerals are very sensitive to alteration and $\mathrm{Ca}$ is highly mobile in soils, this pole corresponds to relatively unaltered materials.

The Oligocene plateau alluvium and Eocene molasses (e6-7) are differentiated on the basis of their potassium content (plus $\mathrm{Rb}$ and to a lesser extent $\mathrm{Sr}$, which generally substitute $\mathrm{K}$ in silicates), mainly associated with $\mathrm{K}$ feldspars and muscovite (Salminen, 2005).

The residual clays derived from weathering of the Cretaceous limestone are characterized by their high $\mathrm{Ti}, \mathrm{Zr}, \mathrm{Fe}$ and $\mathrm{Mn}$ content as oxides and, for Fe, as silicates resistant to alteration (tourmaline, staurolite, garnet).

The coversands are dominated by quartz (pole Si), whereas the aeolian silts also contain a certain percentage of iron oxides. $\mathrm{Zn}, \mathrm{Ni}, \mathrm{Cr}$ and $\mathrm{Y}$, which plot between $\mathrm{Fe}$ and $\mathrm{Si}$, are probably associated with resistant silicates, such as garnet (Salminen, 2005). Eocene sands (e5) and the Lower Pleistocene alluvial deposits of the Dordogne River (Fv) are of similar composition as the aeolian deposits.

The T3c colluvium shows a strong variability, ranging between the terraces Fx and Fv and the Eocene (e5) sands.

For the fraction finer than $63 \mathrm{~mm}$, the pattern is somewhat different. The Ca pole, which aggregates relatively unaltered deposits, remains unchanged. In contrast, $\mathrm{Si}$, $\mathrm{Ti}$ and $\mathrm{Zr}$ are grouped in the same pole, which corresponds to assemblages dominated by quartz and minerals resistant to alteration. Fe and iron substitution elements, such as $\mathrm{Cr}$, $\mathrm{Ni}$ and $\mathrm{Zn}$, form another pole corresponding to oxides in association with kaolinite. It is opposed to $\mathrm{K}$, coming from clays from the illite group. The distribution of the sedimentary formations indicates that (Fig. 9):

1. The aeolian silts plot near the quartz pole and extendtowards the illite pole.

2. The Eocene (e5) and the Lower Pleistocene alluvial (Fv) units are close to the oxides and kaolinite pole.

3. The T3c unit plots between Late Pleistocene alluvialdeposits and aeolian silts. Note that there is marked similarity in the composition of the silty sand distal lithofacies of the colluvium and the plateau aeolian cover.

The chemical composition of unit T3c thus indicates that the sand fraction corresponds to a mixture of Eocene and Pleistocene alluvial formations outcropping on the slope. The molasses do not appear to have contributed much to their formation. By contrast, the fine-grained fraction shows that contribution of Fx overbank material is unlikely but points towards a more or less distant silty aeolian contribution, similar to that forming the plateau cover. 


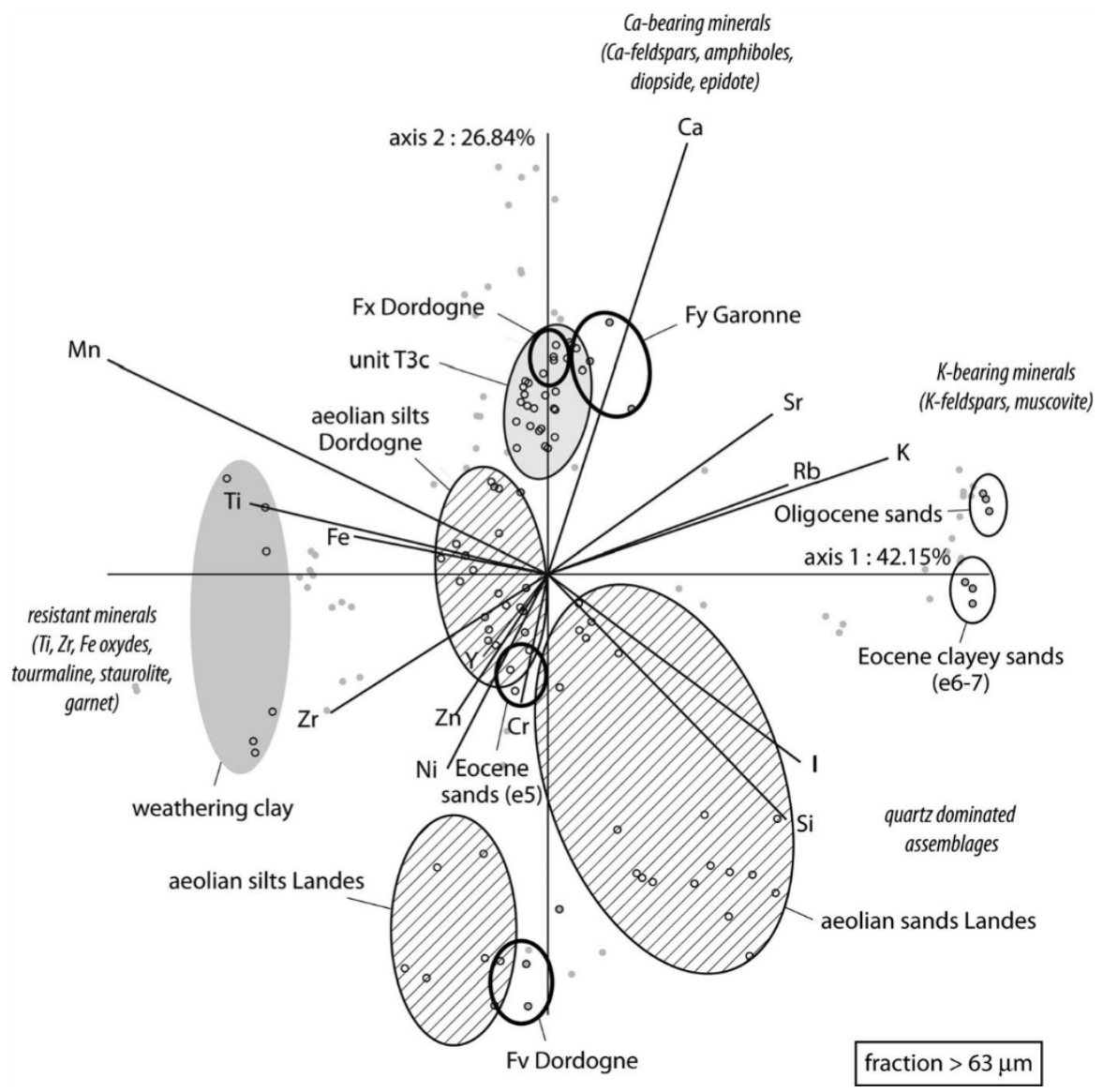

Figure 8. Biplot of the geochemical composition of various geological formations from Aquitaine, fraction $>63 \mathrm{~mm}$. The shaded points correspond to the lithological units used in the analysis but not detailed in the text.

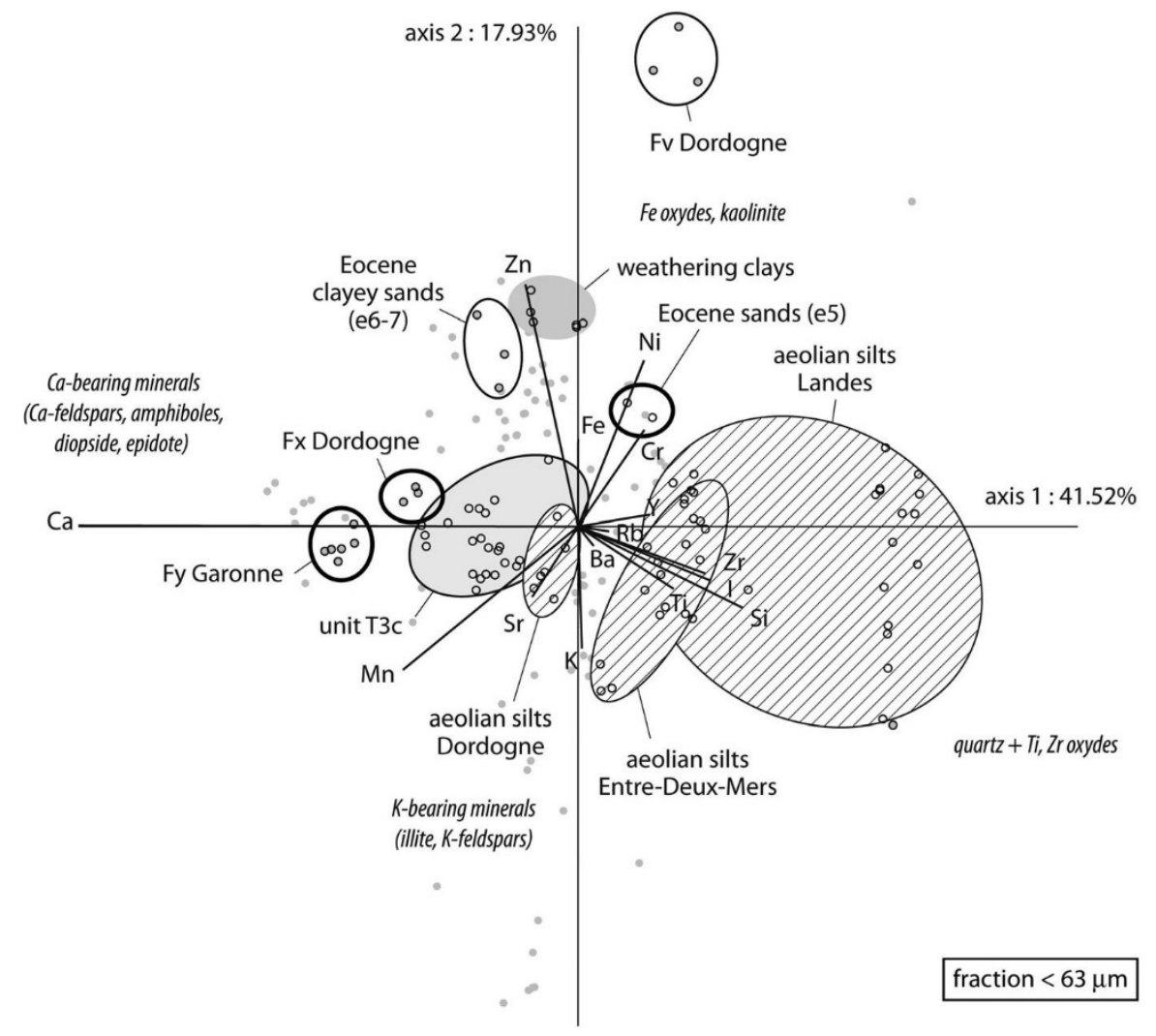

Figure 9. Biplot of the geochemical composition of various geological formations from Aquitaine, fraction $<63 \mathrm{~mm}$. 


\section{Palaeosols}

A pedocomplex typified by two superposed illuvial horizons was observed at Rue Brun at a depth of $2.2 \mathrm{~m}$ in between the colluvial units T3b and c (supporting Fig. S5). The upper horizon (IIBthg) has a sandy silt texture and shows scattered black Fe-Mn coatings and concretions. In thin sections, clayey silt coatings stained brown by organic matter fill a porosity of biological origin (root and animal burrows) (Fig. 10). This palaeosol is interpreted as a greyzem (FAO-WRB, 2006), which suggests a boreal forest or forest-steppe context (Bronger, 1978; Miedema et al., 1999). The underlying IIIBtg horizon displays abundant $\mathrm{Fe}-\mathrm{Mn}$ concretions and bleached degradation tongues. Under the microscope, it corresponds to a polyphased argillic horizon (Fig. 11). A first generation of thick, hydromorphic, light brown clay coatings is visible in the lower part of the horizon. The coatings are fragmented by frost and are covered by humic illuvial clay. This palaeosol has an interglacial rank and is similar to the EemianEarly Glacial luvisol described elsewhere in France (Fe'doroff and Goldberg, 1982; Antoine, 2002; Locht et al., 2003).

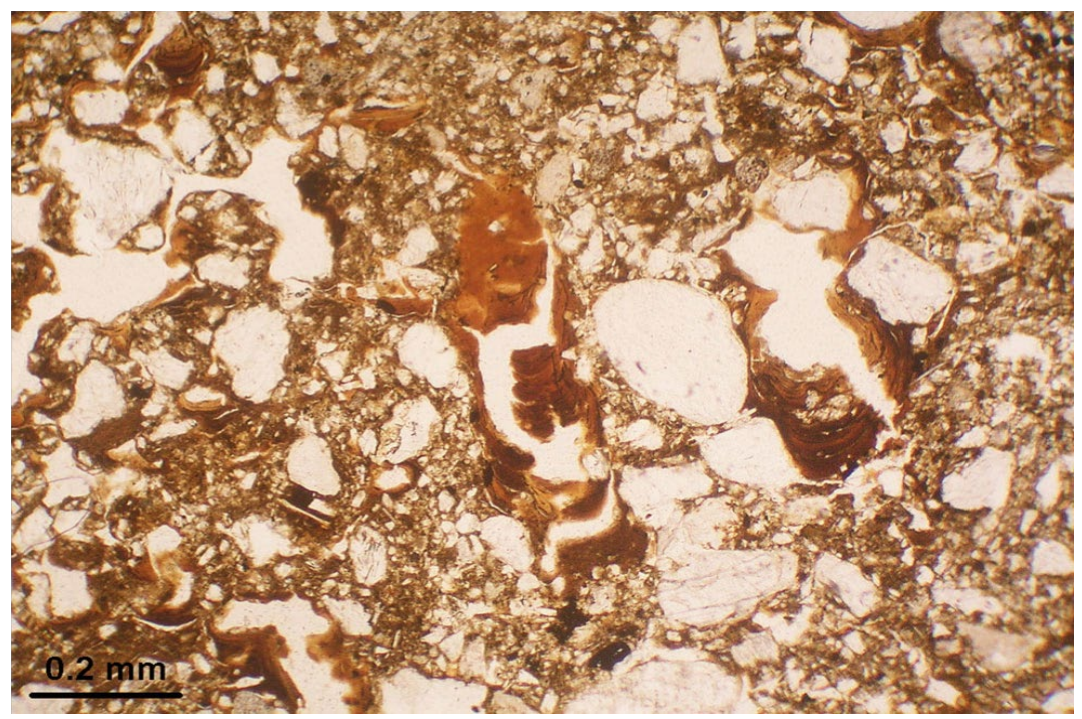

Figure 10. Humic clay coatings, horizon IIBth, thin section 1.

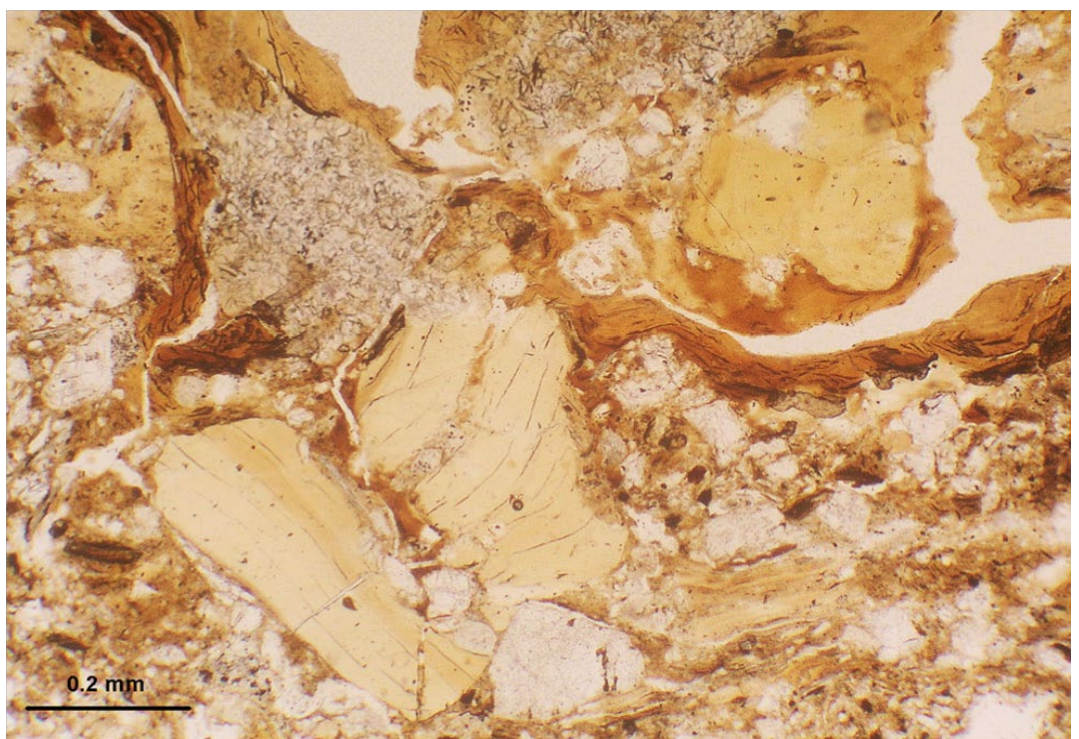

Figure 11. Light brown, microlaminated clay coatings fragmented by frost and overlain by humic clay coatings, horizon IIIBt, thin section 3 . 


\section{Chronology}

Twenty-six radiocarbon, OSL and IRSL age estimations were obtained during the archaeological surveys (Table

1). The main chronological information is as follows (Fig. 12):

1. The T3c colluvial fans yielded OSL/IRSL ages rangingbetween 38.8 (lower boundary at $68 \%$ probability) and $16.3 \mathrm{ka}$ (upper boundary at 68\% probability). Discoveries of Aurignacian (40-31 cal ka BP, Higham et al., 2011; Bradtmo“1ler et al., 2012) and Magdalenian remains (20- 14 cal ka BP, Langlais et al., 2012; Ducasse, 2012) are consistent with this age range. Fan sedimentation thus extended over Marine Isotopic Stage (MIS) 2 and late MIS 3 and is thought to reflect an increase in slope dynamics due to the installation of periglacial conditions in the region. The silt component of the deposits appears to come from distant aeolian inputs, connected with the development of coversands and associated peripheral loess during the Late Pleniglacial in the nearby Landes region (Bertran et al., 2011). Unit T3c is separated by a major unconformity from the underlying units, which remains undated. However, the interglacial ranking palaeoluvisol at the top of T3b, presumed to be Eemian Early Glacial (MIS 5) in age, suggests that the units T3a and $b$ belong to the Saalian (MIS 6).

2. The lateral accretion gravel unit and the associated sanddeposits (T2b) yield IRSL ages contemporaneous with the Late Pleniglacial (MIS 2) and the Lateglacial (18.7-10.1 ka, 68\%). For an unknown reason, the two IRpostIR dates on sand strata intercalated within gravels gave an age close to $8 \mathrm{ka}$ at the Nauve site. In so far as the dated levels are unambiguously older than the gyttjas, these ages are considered unreliable (even when considering the $2 \mathrm{~s}$ interval). At Gilets 2, the sandy point bar unit at the bottom of a T2c channel fill is dated between 12.2 and $10.6 \mathrm{ka}$ (68\%) and show that the channel was still active during the Preboreal chronozone, although flow power reduced significantly.

3. The radiocarbon ages obtained from the gyttjas are closeto each other and contemporary with the Preboreal and Boreal chronozones (11.6-9.6 cal ka BP, 95\% probability). It remains difficult to decide whether the age scatter for the samples taken at the bottom of the gyttjas reflect uncertainties due to sampling or actual differences in the beginning of organic sedimentation. As the samples were retrieved from distant sites, which obviously correspond to distinct fills (see location of Pre' Fagnoux, Gilets 1-2 and Reclaussoux 1 in Fig. 1), these ages suggest that multiple coexisting channels were abandoned virtually simultaneously at the beginning of the Holocene. The channels were also affected by the formation of dolines presumably because of organic matter accumulation and consecutive acidification of the pools. These data indicate that the Lateglacial and the very early Holocene were typified by an anabraching fluvial style (Eaton et al., 2010), then that the river bed reduced to a single active channel during the course of the Preboreal period. Sandy silt overbank deposits plugged the abandoned channels and formed levees until about $5 \mathrm{cal}$ ka BP. Then, vertical accretion of the floodplain became negligible during the rest of the Holocene.

4. The filling of a unique channel located on the northernedge of the Fx terrace yielded relatively recent ages, ranging between 2.8 and $0.7 \mathrm{cal}$ ka BP (95\%). This channel was taken by a small tributary of the Dordogne River and clearly recorded a complex history during the Holocene. 


\begin{tabular}{|c|c|c|c|c|c|}
\hline Site (Radiocarbon) & Unit & Laboratory code & Material & Age $\left({ }^{14} \mathrm{C}\right.$ a BP $)$ & Age (cal a BP) (2s) \\
\hline & & & & 253654 & \\
\hline Cablanc & $\mathrm{T} 2 \mathrm{c}$ & Erl-11647 & Charcoal & & 2756-2367 903- \\
\hline Cablanc & $\mathrm{T} 2 \mathrm{c}$ & Erl-11648 & Charcoal & \multirow{2}{*}{45608255160} & 670 \\
\hline Gilets 1 & $\mathrm{~T} 2 \mathrm{c}$ & Beta-132 375 & Charcoal & & $5450-4979$ \\
\hline Gilets 1 & $\mathrm{~T} 2 \mathrm{c}$ & Beta-132 374 & Charcoal (a) & \multirow{2}{*}{9790120986045} & $11613-10757$ \\
\hline Gilets 2 & $\mathrm{~T} 2 \mathrm{c}$ & GrA-48340 & Peat (b) & & $11385-11199$ \\
\hline Gilets 2 & $\mathrm{~T} 2 \mathrm{c}$ & GrA-48337 & Charcoal & 94204550 & $10758-10520$ \\
\hline Gilets 2 & $\mathrm{~T} 2 \mathrm{c}$ & GrA-48336 & Charcoal & 9420 & $10773-10509$ \\
\hline Pineuilh & $\mathrm{T} 2 \mathrm{c}$ & VERA-4272 & Peat & \multirow{2}{*}{889540} & $10191-9828$ \\
\hline Pre' Fagnoux & $\mathrm{T} 2 \mathrm{c}$ & VERA-4175 GrA- & Peat (b) & & $10703-10498$ \\
\hline Poudrerie & $\mathrm{T} 2 \mathrm{c}$ & 48341 & Charcoal & 937040 & $5638-5441$ \\
\hline Re'claussoux & $\mathrm{T} 2 \mathrm{c}$ & Beta-125 411 & Wood & 481088204070 & $10172-9630$ \\
\hline Re'claussoux & $\mathrm{T} 2 \mathrm{c}$ & Beta-125 410 & Wood (b) & 927060 & $10640-10255$ \\
\hline Site (OSL/IRSL) & Unit & Laboratory code & Material & Date type & Age (ka) \\
\hline$\overline{\text { Tour Ouest }}$ & T3c & Bdx-14820 & Feldspar & IR-post-IR & 201.6 \\
\hline Tour Ouest & $\mathrm{T} 3 \mathrm{c}$ & Bdx-14819 & Feldspar & IR-post-IR & \multirow[t]{2}{*}{21.51 .7} \\
\hline Tour Ouest & $\mathrm{T} 3 \mathrm{c}$ & Bdx-14818 & Feldspar & IR-post-IR & \\
\hline Tour Ouest & $\mathrm{T} 3 \mathrm{c}$ & Bdx-14817 OxL-2079 & Feldspar Quartz & IR-post-IR & \multirow[t]{2}{*}{35.931 .92 .92 .5} \\
\hline Galinoux Cablanc & $\mathrm{T} 3 \mathrm{c}$ & OxL-CablancD4 & Quartz & OSL & \\
\hline Cablanc Gilets & $\mathrm{T} 2 \mathrm{~b}$ & OxL-CablancD5 Bdx-14811 & Quartz & OSL & 17.81 .5 \\
\hline 2 & $\mathrm{~T} 2 \mathrm{~b}$ & Bdx-14813 & Feldspar & OSL & \multirow{2}{*}{14.131 .43} \\
\hline Gilets 2 & $\mathrm{~T} 2 \mathrm{~b}$ & Bdx-14814 & Feldspar & IR & \\
\hline Gilets 2 & $\mathrm{~T} 2 \mathrm{~b}$ & Bdx-14807 & Feldspar & IR & \multirow[t]{2}{*}{17.122 .21 .56} \\
\hline Poudrerie & $\mathrm{T} 2 \mathrm{~b}$ & Bdx-14808 & Feldspar & IR & \\
\hline Poudrerie & $\mathrm{T} 2 \mathrm{~b}$ & Bdx-15492 & Feldspar & IR & 15.6 \\
\hline La Nauve 1 & $\mathrm{~T} 2 \mathrm{~b}$ & Bdx-15493 & Feldspar & IR & 11.91 .1 \\
\hline \multirow[t]{5}{*}{ La Nauve 2} & $\mathrm{~T} 2 \mathrm{~b}$ & & Feldspar & IR-post-IR & 111.2 \\
\hline & $\mathrm{T} 2 \mathrm{~b}$ & & & IR-post-IR & \\
\hline & & & & & 11.512 .21 .12 .1 \\
\hline & & & & & 7.80 .7 \\
\hline & & & & & 7.90 .7 \\
\hline
\end{tabular}

Table 1. Radiocarbon and OSL/IRSL dates from the lower terraces of the Dordogne River. The radiocarbon dates were calibrated with the Calib. Rev. 6.1.0 program and the IntCal09 calibration curve (Reimer et al., 2009). IRSL and IR/ post-IR ages were corrected for fading at rates of 3.5 and $1 \%$, respectively. IR/post-IR ages also take account of a residual level of leaching equivalent to 5 Gy. (a) Bottom of finegrained channel fill, (b) bottom of gyttja/peat layer. 


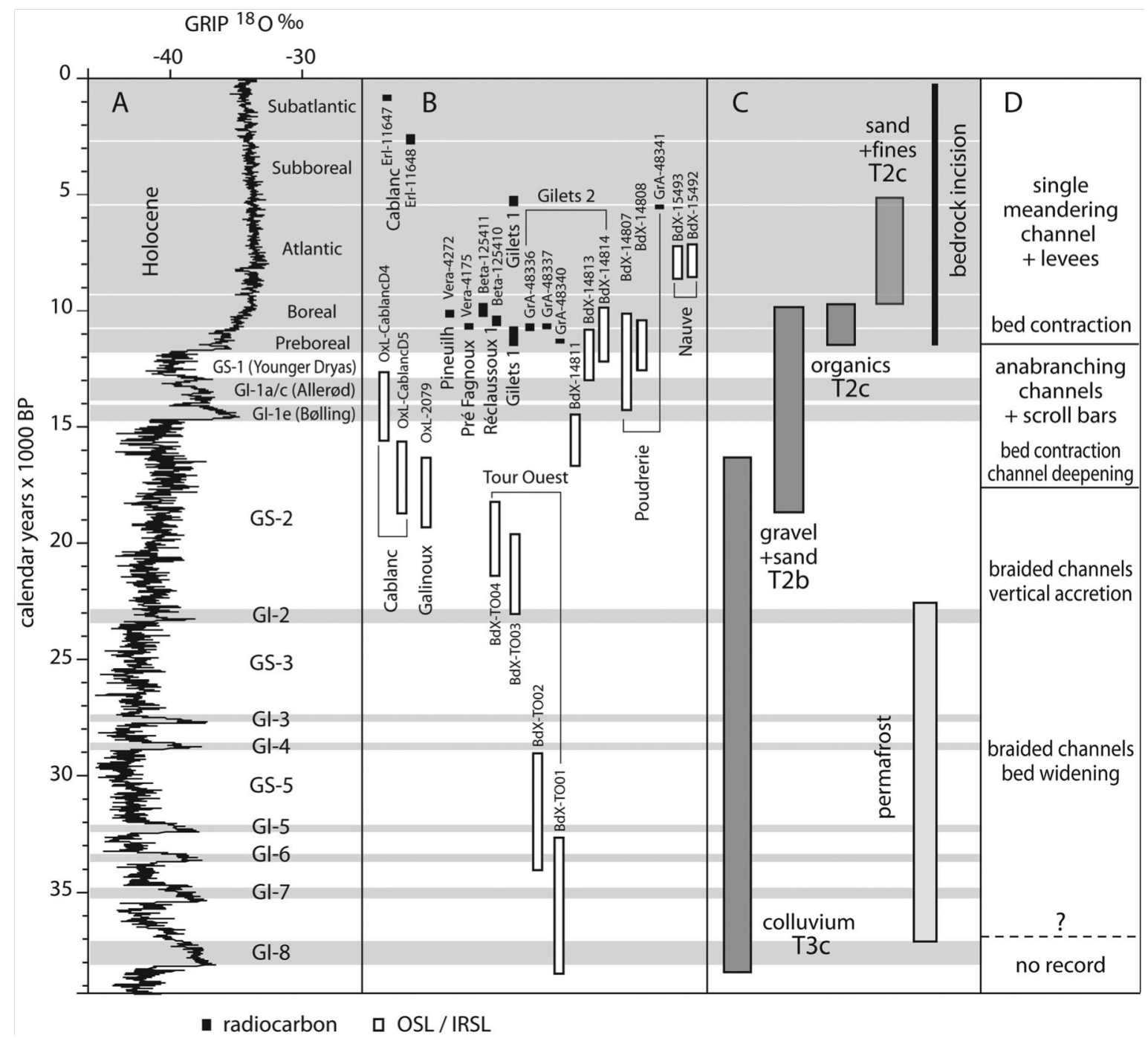

Figure 12. (A) ${ }^{18} \mathrm{O}$ GRIP curve tuned to the GIC05 timescale (Blockley et al., 2012); (B) radiocarbon and OSL ages obtained from the lower Dordogne terraces; (C) $68 \%$ probability intervals for the age of the various lithological units; permafrost data are taken from Bertran et al. (2013); (D) inferred fluvial dynamics.

\section{Discussion}

The abundant data collected in a restricted area of the Dordogne valley near Bergerac bring to light the complexity of the internal architecture of the lower terraces and allow us to establish a detailed chronological framework of the fluvial evolution during the last glacial-interglacial transition period. The chronological data are more limited before MIS 2; nonetheless they enable us to address general issues and to evaluate the relevance of the available conceptual models for river terrace formation in the study area.

The Weichselian Late Pleniglacial was marked by a major change in fluvial drainage pattern, which shifted from a braided to an anabranching one. This change pre-dates the Pleniglacial-Bølling transition (i.e. $14.6 \mathrm{ka}$ ) by $2-3$ millennia, supposedly in response to the development of vegetation and consecutive stabilization of the river banks (Huisink et al., 2002; Vandenberghe, 2003; Horn et al., 2012; Turner et al., 2013). A similar shift from braiding to meandering or anabranching has already been described for many other rivers from northern Europe (Antoine et al., 2003; Kasse et al., 2005; Erkens et al., 2011; Janssens et al., 2012), where it appears to have occurred significantly later and is thought to have coincided more tightly with the onset of the Bølling warming. This may 
have resulted from the latitudinal difference between the areas under investigation and from the delayed development of vegetation in northern Europe following deglaciation.

The Late Pleniglacial and Lateglacial globally appear to have been characterized by multiple anabranches moving laterally on the alluvial plain. Increase in the cross-sectional area of the channels was not accompanied by any significant incision of the underlying limestone bedrock. The erosion of the Pleniglacial gravels primarily reflects adjustment of channel size to increase in mean discharge. Accordingly, data from speleothems (Genty et al., 2005) as well as pollen (Jost et al., 2005) show that mean annual precipitation was close to $300 \mathrm{~mm}$ in south-west France during the Last Glacial Maximum i.e. about one-third of the current one, and raised stepwise to the present level during the Lateglacial and the early Holocene. Point bar accretion occurred following meander shifting and was accompanied by the formation of scroll bars. No evidence for channel abandonment and oxbow lake formation with clay or peat infilling has been found in the Fx terrace (possibly because of subsequent erosion), in contrast to the nearby Caudeau River, a small tributary of the Dordogne. The Brunetie're site (Fig. 1), ca. 3km north-west from the study area, yielded a sequence of bedded clay and gyttja extending over the entire Bølling (Bertran et al., 2009), which may have formed in the context of a small lake due to meander cutoff or channel avulsion.

River shrinkage and abandonment of most of the channels occurred within the course of the Preboreal chronozone (sandy point bar formed until $10.6 \mathrm{ka}$ ) and organic sedimentation took place during the Boreal. As no coarsegrained channel deposits post-dating this period have been found in the Fx terrace, we presume that channel incision took place at this time. Since medieval archaeological finds in the Fz floodplain units obviously indicate that these were deposited very recently, it is assumed that bedrock erosion continued throughout the whole Holocene and entailed vertical deepening of the active channel bed into the Cretaceous limestone by $3-4 \mathrm{~m}$. Incision appears to be disconnected from the periods of change in drainage pattern but corresponds to a long phase of stability of the hydrological regime. The previous phase of significant bedrock incision separates the terraces Fx and Fw3 and remains poorly dated. The presence of an interglacial palaeoluvisol on unit T3b strongly suggests that the gravel unit T3a was deposited during MIS 6, in agreement with earlier proposals (e.g. Texier and Raynal, 1984). We therefore suppose that the incision between the terraces Fw3 and Fx, which is of similar amplitude to the Holocene one, took place during the Eemian interglacial sensu lato (MIS 5). Poor chronological resolution, however, does not allow rejection of alternative hypotheses, such as erosion at the beginning of the last glacial.

These data from the middle course of the Dordogne River only partially fit with the most acknowledged conceptual model proposed for terrace formation (see Vandenberghe, 2003, 2008, and Bridgland and Westaway, 2008 for discussion), which suggests that channel incision occurred essentially during short transitional climatic phases (cold towards temperate or inversely), whereas periods of stability were rather typified by vertical aggradation of the bed. Although channel deepening associated with a change in drainage pattern occurred in connection with the cold-warm Late Pleniglacial transition, the most significant phase of bedrock incision has continued throughout the Holocene. The river obviously kept its capacity to erode the limestone substrate during the whole Holocene in association with forest development on the catchment, low sediment delivery from hillslopes and increased mean discharge. Limestone dissolution may have played a non-negligible role in bedrock incision. Unlike in the lower reaches of the Dordogne River and seemingly because of a higher uplift rate, erosion was sufficiently important for the Pleniglacial-Lateglacial terrace to be beyond the reach of floods and for aggradation by overbank deposits to become insignificant after $5 \mathrm{ka}$. 
By contrast, the data obtained on terrace Fx corroborate the hypothesis of substratum planation and bed widening during cold periods, as discussed by Lewin and Gibbard (2010). The large lateral development of the terrace seems to be a legacy from unit T2a emplacement, which was typified by braiding. This unit has not yet been dated; however, deposition pre-dates 18-17 ka and is assumed to have occurred during late MIS 3 and early MIS 2 in the context of a periglacial environment. An OSL age of $272 \mathrm{ka}$ was obtained on an equivalent gravel unit from the nearby Isle valley and is in accordance with this hypothesis (Brenet et al., 2013). Widening of the bed during the course of the Late Pleniglacial resulted in the erosion of previous Weichselian alluvial deposits; subsequently, no Early Glacial to Middle Pleniglacial units have yet been clearly identified. Murton and Belshaw (2011) suggested that planation was linked to the development of permafrost and associated brecciation of bedrock due to ice segregation. In such context, bed widening rather than downcutting was favoured by thermokarstic erosion of the banks. Available chronological data for Pleistocene permafrost in Aquitaine (Guhl et al., 2012; Lenoble et al., 2012; Bertran et al., 2013) show that such a hypothesis remains plausible for the Dordogne River, even though it is located at relatively low latitude $\left(45^{\circ} \mathrm{N}\right)$. OSL ages obtained from the aeolian fill of wedge structures around Bordeaux indicate that episodes of permafrost development occurred in Aquitaine between 36 and $23 \mathrm{ka}$. These episodes probably lasted for no longer than a millennium (Bertran and Fabre, 2005) but may have had a major influence on fluvial dynamics. Aggradation of the gravel bed then continued in a periglacial context but probably without permafrost until about $17 \mathrm{ka}$, in connection with intense mass wasting and overland flow on the hillslopes as testified by the emplacement of thick colluvial deposits on higher terraces (T3c unit). Large volumes of glacigenic debris may also have been supplied by headwater sources (Veyret, 1986).

Overall, the gravel material deposited during the end of the Late Pleniglacial and the Lateglacial represents a significant part of the volume of Fx in the investigated area, and older sand and gravel deposits are only preserved as isolated bodies in the terrace. Global attribution of the gravel sheet to the Weichselian Pleniglacial, as often proposed, appears thus to be erroneous.

\section{Conclusions}

The lower Dordogne terraces at Bergerac, south-west France, were studied in detail using cores, trenches, GPR profiles, and ${ }^{14} \mathrm{C}$ and OSL/IRSL dating. The main results of this study are as follows:

1. The Fx terrace comprises two main architectural elements: (i) a dominantly horizontally bedded gravel unit deposited in a braided river, and (ii) gravel point bars that reflect lateral shifting of large anabranching channels. The first unit is Middle to Late Pleniglacial in age while the second corresponds to the Late Pleniglacial and Lateglacial. In terms of volume, the contribution of both units to the formation of the Fx terrace is broadly equivalent.

2. The most recent phase of bedrock incision occurredthroughout the Holocene. This long phase of incision took place in a meandering river within densely vegetated landscape and seems to be out of phase with the periods of rapid reorganization of the channel pattern following climate changes.

3. The presence of an interglacial (Eemian-Early Glacial) palaeoluvisol above the Fw3 gravels indicates that this terrace formed before MIS 5. The phase of incision that separates Fx and Fw3 is of similar amplitude to the Holocene one and is tentatively correlated with MIS 5. 
4. The lateral development of Fx was associated withchannel braiding in a periglacial context. Bedrock planation and bank undercutting were triggered by permafrost development during late MIS 3 and early MIS 2. Vertical gravel aggradation was then promoted by large inputs of hillslope-derived debris probably in a seasonal frost context. Thick colluvial fans formed subsequently on the higher terraces. Braidplain abandonment and transition to an anabranching river took place during the Late Pleniglacial, around 18-17 ka.

5. The Lateglacial does not correspond to disruption of thefluvial regime. The Late Pleniglacial anabranches persisted throughout the Lateglacial. The channels were all abandoned more or less simultaneously during the Preboreal.

6. Until about $5 \mathrm{ka}$, the channels were filled by gyttjas thenby sandy silt overbank deposits. After this time, floodplain accretion becomes insignificant. Tectonic uplift may explain why, unlike for other rivers in Europe (Pastre et al., 2001; Antoine et al., 2003; Macklin et al., 2010; Morin et al., 2010; Erkens et al., 2011), increased suspension load during the Holocene due to anthropogenic activities in the catchment did not lead to significant floodplain accretion during the last five millennia.

\section{Supporting Information}

Additional supporting information can be found in the online version of this article:

Fig. S1. General cross-section of the Dordogne valley at Bergerac and location of the main archaeological finds.

Fig. S2. Lithological cross-section at Pre' Fagnoux.

Fig. S3. Lithological cross-section at Gilets 2. Fig. S4. Lithological cross-section at De'viation Ouest - phase 1.

Fig. S5. View of the palaeoluvisol at Rue Brun.

\section{Acknowledgements}

We extend warm thanks to all the INRAP operation directors that made it possible to collect the data presented here, namely P. Bidart, C. Ballarin, M. Folgado, P. Foue're', F. Grigoletto and B. Poissonnier, as well as M. Regeard (CG Dordogne) for additional documentation. We also acknowledge financial support from the Inrap, the ANR project 'Magdatis' and the European Research Council (FP7/2007/2013, TRACSYMBOLS 249587). D. Bridgland and J. Vandenberghe contributed to improve the manuscript.

Abbreviations. ED-XRF, energy-dispersive X-ray-fluorescence; GPR, ground penetrating radar; IRSL, infrared stimulated luminescence; MIS, Marine Isotope Stage; OSL, optically stimulated luminescence; SAR, single aliquot regenerative dose. 


\section{References}

Aitchison J. 1982. The statistical analysis of compositional data. Journal of the Royal Statistical. Society. Series B: Statistical Methodology 44: 134-177.

Aitchison J, Greenacre M. 2002. Biplots of compositional data. Applied Statistics 51: 375-392.

Antoine P. 2002. Les lœss en France et dans le Nord-Ouest europe'en. Revue Franc, aise de Ge'otechnique 99: 321.

Antoine P, Munaut AV, Limondin-Lozouet N, et al. 2003. Response of the Selle river to climatic modifications during the Lateglacial and Early Holocene (Somme Basin, Northern France). Quaternary Science Reviews 22: 2061-2076.

Auclair M, Lamothe M, Huot S. 2003. Measurement of anomalous fading for feldspar IRSL using SAR. Radiation Measurements 37: 487-492.

Bertran P, Allenet G, Fourbouley C, et al. 2009. Pale'oenvironnements tardiglaciaires en Aquitaine: la se'quence alluviale de La Brunetie`re. Quaternaire 20: 161-193.

Bertran P, Andrieux E, Antoine P, et al. 2013. Distribution and chronology of Pleistocene permafrost features in France: database and first results. Boreas doi: 10.1111/bor.12025

Bertran P, Bateman M, Hernandez M, et al. 2011. Inland aeolian deposits of southwest France: facies, stratigraphy and chronology. Journal of Quaternary Science 26: 374-388.

Bertran P, Fabre R. 2005. Pleistocene cryostructures and landslide at Petit-Bost (south-western France, $45^{\circ}$ N). Geomorphology 71: 344-356. Blockley SPE, Lane PS, Hardiman M, et al. INTIMATE members. 2012. Synchronisation of palaeoenvironmental records over the last 60,000 years, and an extended INTIMATE1 event stratigraphy to 48,000 b2k. Quaternary Science Reviews 36: 2-10.

Bradtmo"1ler M, Pastoors A, Weninger B, et al. 2012. The repeated replacement model - Rapid climate change and population dynamics in Late Pleistocene Europe. Quaternary International 247: 38-49.

Brenet M, Bertran P, Claud E, et al. 2013. Boulazac-Landry. Rapport Final d'Ope'ration unpublished Report, INRAP, Pessac.

Bridgland DR, Westaway R. 2008. Climatically controlled river terrace staircases: a worldwide Quaternary phenomenon. Geomorphology 98: 285-315.

Bridgland DR, Westaway R. 2012. The use of fluvial archives in reconstructing landscape evolution: the value of sedimentary and morphostratigraphical evidence. Netherlands Journal of Geosciences 91: 5-24.

Bronger A. 1978. Climatic sequences of steppe soils from eastern Europe and the USA with emphasis on the genesis of the 'argillic horizon'. Catena 5: 33-51.

Buccianti A. 2012. Is compositional data analysis a way to see beyond the illusion? Computers and Geosciences 50: $165-173$.

Buylaert JP, Murray AS, Thomsen KJ, et al. 2009. Testing the potential of an elevated temperature IRSL signal from K-feldspar. Radiation Measurements 44: 560-565.

Ducasse S. 2012. What is left of the Badegoulian 'interlude'? New data on cultural evolution in southern France between 23,500 and 20,500 cal. BP. Quaternary International 272-273: 150-165.

Eaton BC, Millar RG, Davidson S. 2010. Channel patterns: braided, anabranching, and single-thread. Geomorphology 120: 353-364. 
Erkens G, Hoffmann T, Gerlach R, et al. 2011. Complex fluvial response to Lateglacial and Holocene allogenic forcing in the Lower Rhine Valley (Germany). Quaternary Science Reviews 30: 611-627.

FAO-WRB. 2006. World Reference Base for Soil Resources 2006. World Soil Resources report 103. Food and Agriculture Organization of the United Nations: Rome.

Fe'doroff N, Goldberg P. 1982. Comparative micromorphology of two late Pleistocene paleosols (in the Paris Basin). Catena 9: 227-251.

Genty D, Combourieu-Nebout N, Hatte' C, et al. 2005. Rapid climatic changes of the last 90 kyr recorded on the European continent. Comptes Rendus - Geosciences 337: 970-982. Grigoletto F. 2010. Les Libraires. Unpublished Report. Inrap Grand Sud-Ouest: Pessac.

Guhl A, Bertran P, Fitzsimmons KE, et al. 2012. Optically stimulated luminescence (OSL) dating of sand-filled wedges structures and their alluvial host sediments from Jonzac, Southwest France. Boreas 10.1111/j.15023885.2012.00270.x.

Guillore' P. 1980. Me'thode de fabrication me'canique et en se'rie des lames minces. Institut National d'Agronomie: Paris.

Harvey AM. 1997. The role of alluvial fans in arid zone fluvial systems. In Arid Zone Geomorphology: Process, Form and Change in drylands, Thomas DSG (ed), 2nd edn. Wiley: Chichester; 231- 259.

Higham T, Jacobi R, Basell L, et al. 2011. Precision dating of the Palaeolithic: a new radiocarbon chronology for the Abri Pataud (France), a key Aurignacian sequence. Journal of Human Evolution 61: 549-563.

Horn JD, Joeckel RM, Fielding CR. 2012. Progressive abandonment and planform changes of the central Platte River in Nebraska, central USA, over historical timeframes. Geomorphology 139-140: 372-383.

Huisink M, de Moor JJW, Kasse C, et al. 2002. Factors influencing periglacial fluvial morphology in the northern European Russian tundra and taiga. Earth Surface Processes and Landforms 27: 1223- 1235.

Janssens MM, Kasse C, Bohncke SJP, et al. 2012. Climate-driven fluvial development and valley abandonment at the last glacial- interglacial transition (Oude IJssel-Rhine, Germany). Netherlands Journal of Geosciences 91: $37-62$.

Jost A, Lunt D, Kageyama M, et al. 2005. High-resolution simulations of the last glacial maximum climate over Europe: a solution to discrepancies with continental palaeoclimatic reconstructions? Climate Dynamics 24: $557-$ 590.

Kasse C, Hoek WZ, Bohncke SJP, et al. 2005. Lateglacial fluvial response of the Niers-Rhine (western Germany) to climate and vegetation change. Journal of Quaternary Science 20: 377- 394.

Langlais M, Costamagno S, Laroulandie V, et al. 2012. The evolution of Magdalenian societies in South-West France between 18,000 and 14,000 calBP: changing environments, changing tool kits. Quaternary International 272-273: 138-149.

Leclerc RF, Hickin EJ. 1997. The internal structure of scrolled floodplain deposits based on ground-penetrating radar, North Thompson River, British Columbia. Geomorphology 21: 17-38.

Lenoble A, Bertran P, Mercier N, et al. 2012. Le site du Lac Bleu et la question de l'extension du perge'lisol en France au Ple'istoce'ne supe'rieur. In Quaternaire continental d'Aquitaine: un point sur les travaux re'cents, Livret-guide de l'excursion AFEQ-ASF, 2012, Bertran P, Lenoble A (eds). Universite' de Bordeaux, AFEQ: 107121. 
Lewin J, Gibbard PL. 2010. Quaternary river terraces in England: forms, sediments and processes. Geomorphology 120: $293-311$.

Locht JL, Antoine P, Bahain JJ, et al. 2003. Le gisement pale'olithique moyen et les se'quences ple'istoce'nes de Villiers-Adam (Val d'Oise, France): Chronostratigraphie, Environnement et Implantations humaines. Gallia Pre'histoire 45: 1-111.

Lunt IA, Bridge JS. 2004. Evolution and deposits of a gravelly braid bar, Sagavanirktok River, Alaska. Sedimentology 51: 415-432.

Macklin MG, Jones AF, Lewin J. 2010. River response to rapid Holocene environmental change: evidence and explanation in British catchments. Quaternary Science Reviews 29: 1555-1576.

Martin-Fernandez JA, Barcelo-Vidal C, Pawlowsky-Glahn V. 2003. Dealing with zeros and missing values in compositional data sets using nonparametric imputation. Mathematical Geology 35: 253-278.

Miall AD. 1996. The Geology of Fluvial Deposits. Springer: Berlin. Miedema R, Koulechova IN, Gerasimova MI. 1999. Soil formation in Greyzems in Moscow district: micromorphology, chemistry, clay mineralogy and particle size distribution. Catena 34: 315-347.

Morin E, Macaire JJ, Hinschberger F, et al. 2010. Spatio-temporal evolution of the Choisille River (southern Parisian Basin, France) during the Weichselian and the Holocene as a record of climate trend and human activity in north-western Europe. Quaternary Science Reviews 30: 347-363.

Murray AS, Wintle AG. 2000. Luminescence dating of quartz using an improved single-aliquot regenerative-dose protocol. Radiation Measurements 32: 57-73.

Murton JB, Belshaw RK. 2011. A conceptual model of valley incision, planation and terrace formation during cold and arid permafrost conditions of Pleistocene southern England. Quaternary Research 75: 385-394.

Pastre JF, Limondin-Lozouet N, Gebhardt A, et al. 2001. Lateglacial and Holocene fluvial records from the central part of the Paris Basin (France). In River Basin Sediment Systems: Archives of Environmental Change, Maddy D, Macklin MG, Woodward J (eds). Balkema: Rotterdam; 357-373.

Platel JP. 1985. Bergerac. 1:50 000 Geological map of France. BRGM: Orle'ans.

Prodeo F, Sireix C, Deloze V, et al. 2001. Bergerac. RN21-section sud. Unpublished report, Inrap Grand SudOuest: Pessac.

Reimer PJ, Baillie MGL, Bard E, et al. 2009. IntCa109 and Marine09 radiocarbon age calibration curves, 0-50,000 years cal BP. Radiocarbon 51: 1111-1150.

Salminen R. 2005. Geochemical atlas of Europe. Foregs, IUGS/IAGC Global Geochemical Baselines. weppi.gtk.fi/publ/foregsatlas/index. php.

Sambrook GH, Ashworth PJ, Best JL, et al. 2006. The sedimentology and alluvial architecture of the sandy braided South Saskatchewan River, Canada. Sedimentology 53: 413-434.

Texier JP, Raynal JP. 1984. Les de'po`ts et les terrasses fluviatiles d'Aquitaine et du Massif Central. Bulletin de 1'Association Franc, aise pour l'Etude du Quaternaire 1-2-3: 67-71.

Thio-Henestrosa S, Comas M. 2011. CoDaPack v.2 user's guide, ima. udg.edu/codapack/assets/codapackmanual.pdf.

Thomsen KJ, Murray AS, Jain M, et al. 2008. Laboratory fading rates of various luminescence signals from feldspar-rich sediment extracts. Radiation Measurements 24: 473-477. 
Turner F, Tolksdorf JF, Viehberg F, et al. 2013. Lateglacial/early Holocene fluvial reactions of the Jeetzel river (Elbe valley, northern Germany) to abrupt climatic and environmental changes. Quaternary Science Reviews 60: 91-109.

Van Vliet-Lanoe" B. 1985. Frost effects in soils. In Soils and Quaternary Landscape Evolution, Boardman J (ed). Wiley: Chichester; $117-158$.

Vandenberghe J. 2003. Climate forcing of fluvial system development: an evolution of ideas. Quaternary Science Reviews 22: 2053-2060.

Vandenberghe J. 2008. The fluvial cycle at cold-warm-cold transitions in lowland regions: a refinement of theory. Geomorphology 98: 275-284.

Vandenberghe J, van Overmeeren RA. 1999. Ground penetrating radar images of selected fluvial deposits in the Netherlands. Sedimentary Geology 128: 245-270.

Veyret Y. 1986. Quaternary glaciations in the French Massif Central. Quaternary Science Reviews 5: 395-396. 3. 